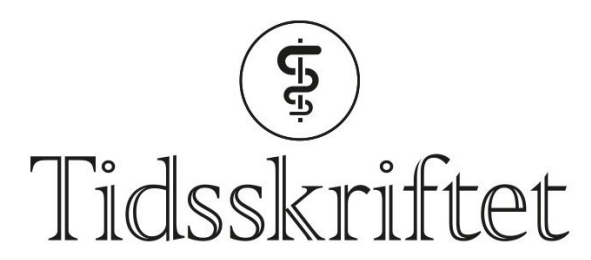

DEN NORSKE LEGEFORENING

\title{
Kompleksitetsteori har begrenset nytte
}

KOMMENTAR

\section{CARL-FREDRIK BASS $\varnothing$ E}

E-post: bassoe.carl@gmail.com

Carl-Fredrik Bassøe er leder i medisinsk informatikk ved EkviMed AS.

Ingen oppgitte interessekonflikter.

Lars Prag Antonsen sin kronikk om kompleksitetsteori er interessant for klinikere og administratorer (1). Teorien har et par begrensninger som ikke berøres. Kaosteori gjelder hovedsakelig for åpne systemer: en sommerfugl i Atlanterhavet kan skape storm i Stillehavet (2). Derimot foregår de fleste biologiske prosesser i isolerte kammer. De fleste molekylære prosesser i hjernen er isolert fra tilsvarende prosesser i alle andre organer. Ulike organeller i samme celle har forskjellige metabolske stier. Forutsigelser fra kaotiske prosesser er kritisk avhengig av initialbetingelsene (3). De er imidlertid ikke tilgjengelige hverken for klinikere eller administratorer. Disse begrensningene reduserer nytten til kompleksitetsteorien.

\section{LITTERATUR:}

1. Antonsen LP. Hva kompleksitetsteori kan lære oss om sykdom og organisering. Tidsskr Nor Legeforen 2019; 139. doi: 10.4045/tidsskr.18.0724. [PubMed][CrossRef]

2. Gleick J. Chaos. London: Vintage, 1998.

3. Barnsley M. Fractals everywhere. Boston: Academic Press, 1988.

Publisert: 11. mars 2019. Tidsskr Nor Legeforen. DOI: 10.4045/tidsskr.19.0152

(C) Tidsskrift for Den norske legeforening 2020. Lastet ned fra tidsskriftet.no 